\title{
Correction to: Safety and efficacy of azilsartan in paediatric patients with hypertension: a phase 3 , single-arm, open-label, prospective study
}

\author{
Shuichi Ito ${ }^{1}\left[\right.$ ? Yuya Nishiyama ${ }^{2} \cdot$ Kenkichi Sugiura $^{2} \cdot$ Kazuaki Enya $^{2}$
}

Published online: 13 January 2022

(c) The Author(s) 2022

\section{Correction to: Clinical and Experimental Nephrology https://doi.org/10.1007/s10157-021-02159-9}

The article "Safety and efficacy of azilsartan in paediatric patients with hypertension: a phase 3, single-arm, openlabel, prospective study", written by Shuichi Ito - Yuya Nishiyama $\cdot$ Kenkichi Sugiura and Kazuaki Enya was originally published Online First without Open Access. With the author(s)' decision to opt for Open Choice the copyright of the article changed on 16th December 2021 to (C) The Author(s) 2021 and the article is forthwith distributed under the terms of the Creative Commons Attribution 4.0 International License (https://creativecommons.org/licenses/by/4. $0 /$ ), which permits use, sharing, adaptation, distribution and reproduction in any medium or format, as long as you give appropriate credit to the original author(s) and the source, provide a link to the Creative Commons licence, and indicate if changes were made.

The original article has been corrected.
The original article can be found online at https://doi.org/10.1007/ s10157-021-02159-9.

Kazuaki Enya

kazuaki.enya@takeda.com

1 Department of Pediatrics, Yokohama City University, Yokohama, Kanagawa, Japan

2 Takeda Development Center Japan, Takeda Pharmaceutical Company Limited, Osaka, Japan
Open Access This article is licensed under a Creative Commons Attribution 4.0 International License, which permits use, sharing, adaptation, distribution and reproduction in any medium or format, as long as you give appropriate credit to the original author(s) and the source, provide a link to the Creative Commons licence, and indicate if changes were made. The images or other third party material in this article are included in the article's Creative Commons licence, unless indicated otherwise in a credit line to the material. If material is not included in the article's Creative Commons licence and your intended use is not permitted by statutory regulation or exceeds the permitted use, you will need to obtain permission directly from the copyright holder. To view a copy of this licence, visit http://creativecommons.org/licenses/by/4.0/.

Publisher's Note Springer Nature remains neutral with regard to jurisdictional claims in published maps and institutional affiliations. 